\author{
KATARZYNA KOPYŚCIAŃSKA \\ ORCID: 0000-0003-1955-5949 \\ Uniwersytet Wrocławski
}

\title{
RODZAJE UPRZEDNICH POROZUMIEŃ CENOWYCH W REGULACJACH USTAWOWYCH I PRAKTYCE ICH STOSOWANIA
}

\begin{abstract}
Abstrakt: Ze względu na swoją doniosłość oraz znaczenie dla finansów publicznych problematyka zapobiegania negatywnemu zjawisku unikania opodatkowania stała się przedmiotem inicjatywy OECD. Celem tej inicjatywy było wyeliminowanie, a przynajmniej znaczne przeciwdziałanie, coraz częstszych praktyk zaniżania podstawy opodatkowania i niekontrolowanego transferu zysków $\mathrm{z}$ jednego państwa do drugiego. Jednym z rozwiązań sprzyjających osiągnięciu wskazanego celu jest możliwość zawierania uprzednich porozumień cenowych. Uprzednie porozumienia cenowe stanowią w tym kontekście ważne także dla podatników rozwiązanie. Przepisy ustawy o rozstrzyganiu sporów dotyczących podwójnego opodatkowania oraz zawieraniu uprzednich porozumień cenowych wskazują na trzy typy (rodzaje) uprzednich porozumień cenowych: jednostronne uprzednie porozumienie cenowe, dwustronne i wielostronne porozumienie cenowe. Dotychczasowa praktyka w Polsce wskazuje, że najczęściej przeprowadzaną procedurą jest wydawanie porozumień jednostronnych.
\end{abstract}

Słowa kluczowe: uprzednie porozumienie cenowe, unikanie opodatkowania, wytyczne OECD, podmioty powiązane

\section{PRZYCZYNY WPROWADZENIA NOWYCH REGULACJI PRAWNYCH}

Zmienność jest cechą immanentną systemów prawnych, a w ciągu ostatnich lat stała się jeszcze bardziej zauważalna. Przepisy prawa podatkowego bardzo często nie nadążają za dynamicznie zmieniającą się gospodarką, zwłaszcza jej cyfrową gałęzią, która oddziałuje na pozostałe. Ale dość powszechnym zjawiskiem, i do pewnego stopnia zrozumiałym, są działania podejmowane przez podatników, zmierzające do minimalizowania obciążeń podatkowych, które z ekonomicznego punktu widzenia traktowane są jako „koszt” działalności gospodarczej. Tak zwane tax avoidance, czyli negatywne zjawisko unikania opodatkowania, realizowane jest najczęściej poprzez tworzenie sztucznych konstrukcji. Jedną z nich jest na przykład podział na kilka etapów jednorodnego gospodarczo zdarzenia. 
Ma to stworzyć mylne wrażenie istnienia kilku odrębnych, niezwiązanych z sobą zdarzeń gospodarczych. Często tak tworzone konstrukcje gospodarcze zawierają elementy wzajemnie się znoszące, a jedynym efektem jest uniknięcie wyższego opodatkowania. Jest to znacznie łatwiejsze w sytuacji zmieniających się dynamicznie mechanizmów gospodarczych, których nie udaje się uchwycić ustawodawcy w odpowiednim momencie.

Przez unikanie opodatkowania, ujmując rzecz w pewnym uproszczeniu, należy rozumieć działania podatników, które co prawda są legalne i zmierzające do wyeliminowania ciężaru podatkowego lub też jego ograniczenia (do poziomu adekwatnego z ekonomicznego punktu widzenia w danej sytuacji), ale są sprzeczne $\mathrm{z}$ intencją prawodawcy czy też $\mathrm{z}$ celem $\mathrm{i}$ istotą regulacji podatkowo-prawnych. $\mathrm{W}$ praktyce oznacza to świadome korzystanie $\mathrm{z}$ różnego rodzaju zwolnień podatkowych, odliczeń i ulg, a w wypadku przedsiębiorcy korzystanie także z różnych, możliwych form opodatkowania przedsiębiorstw ${ }^{1}$.

Problematyka unikania opodatkowania związana jest także nierozłącznie z postępującą globalizacją gospodarki światowej oraz rosnącym znaczeniem holdingów międzynarodowych, w szczególności tych, które działają transgranicznie. $\mathrm{Z}$ działaniem takich podmiotów wiąże się z kolei problematyka cen transferowych, transferu zysków, erozji podstawy opodatkowania przedsięwzięć podejmowanych przez podmioty powiązane, co może mieć istotny wpływ na ostateczny kształt zysków lub strat podatnika wchodzącego w skład grupy kapitałowej. Z tych względów problematyka porozumień cenowych i związanych z nimi cen transferowych jest jedną z ważniejszych z perspektywy polityki podatkowej danego państwa, ale jej znaczenie ma także oczywiście wymiar międzynarodowy.

Ze względu na swoją doniosłość oraz znaczenie dla finansów publicznych problematyka zapobiegania negatywnemu zjawisku unikania opodatkowania stała się przedmiotem inicjatywy OECD, mającej na celu wyeliminowanie, a przynajmniej znaczne przeciwdziałanie, coraz częstszych praktyk zaniżania podstawy opodatkowania i niekontrolowanego transferu zysków z jednego państwa do drugiego. Wynikiem tych prac było opracowanie piętnastu działań, które w swoim zamierzeniu miały wyposażyć rządy oraz międzynarodowe organizacje w instrumenty potrzebne do rozwiązywania problemów BEPS (Base Erosion and Profit Shifting). Nie ulega wątpliwości, iż międzynarodowe organizacje z OECD i Unią Europejską na czele coraz bardziej wnikliwie przyglądają się wszelkim transakcjom mającym znamiona agresywnej optymalizacji podatkowej, umożliwiającym całkowite bądź częściowe uniknięcie obciążeń podatkowych. Szczególną uwagę przykuwają międzynarodowe korporacje posiadające swoje przedstawicielstwa w państwach stosujących preferencyjne systemy podatkowe. Kluczowym zagadnieniem $\mathrm{w}$ tej materii jest problem obustronnego braku opodatkowania czy też

\footnotetext{
${ }^{1}$ Ceny transferowe. Wybrane zagadnienia, red. D. Gajewski, Warszawa 2019, s. 6 n.
} 
stosowanie procedur wzajemnego porozumiewania się na podstawie umów o unikaniu podwójnego opodatkowania².

Postępujące umiędzynarodowienie przedsiębiorstw wynikające $\mathrm{z}$ globalizacji rynków i związana $\mathrm{z}$ tym większa aktywność organów podatkowych $\mathrm{w}$ zakresie kontroli spowodowały, że coraz popularniejsze stało się zagadnienie cen transferowych. Wspomniane przesłanki stanowiły podłoże do wprowadzenia działania nr 13 BEPS, które skupia się na omówieniu dokumentacji i celów jej wprowadzenia dla cen transferowych. Należy również zauważyć, że część postanowień raportów dotyczących przeciwdziałania BEPS, odnoszących się do kwestii cen transferowych, zostało już wprowadzonych do polskiego systemu prawnego - dotyczy to głównie wymogów w zakresie dokumentacji cen transferowych określonych w raporcie z działania $\mathrm{nr} 13$, które znalazły odzwierciedlenie w treści znowelizowanej ustawy o podatku dochodowym od osób fizycznych oraz ustawy o podatku dochodowym od osób prawnych ${ }^{3}$. Jak podkreślają przedstawiciele doktryny, poprzednio obowiązujące regulacje prawne nie były wystarczająco efektywne do identyfikowania mechanizmu stosowania cen transferowych ${ }^{4}$.

Mając na względzie niewiążący charakter współpracy w ramach OECD oraz że raporty powstałe w ramach projektu BEPS są zaliczane do kategorii tak zwanego prawa miękkiego (soft law) ${ }^{5}$, pozytywna reakcja poszczególnych krajów, w tym Polski, była zaskakująco mocna. W ostatnim czasie podjęto szereg działań, które miały na celu implementację rozwiązań zawartych w projekcie BEPS do polskiego porządku prawnego. Dalsze zmiany, nie tylko w ramach pakietu BEPS, stały się bowiem nieuniknione, zważywszy na dynamikę zmian w zachodzących procesach gospodarczych.

Kolejną przyczyną zmian dokonywanych w ostatnich latach była konieczność wdrożenia dyrektywy Rady (UE) 2017/1852 z dnia 10 października 2017 roku w sprawie mechanizmów rozwiązywania sporów dotyczących podwójnego opodatkowania ${ }^{6}$, jak też potrzeba ujednolicania procedur prowadzonych przez właści-

${ }^{2}$ BEPS - czy czekaja nas kolejne zmiany $w$ podatkach i jak się do nich przygotować? Webinarium PwC, Warszawa 2015, s. 4; Ceny tranferowe. Base Erosion and Profit Shifting (BEPS), www.ey.com/pl/pl/services/tax/transfer-pricing-and-operating-model-effectiveness/ey-ceny-trans ferowe-beps (dostęp: 9.05.2020); M. Paszek, Wplyw regulacji międzynarodowych na kształt polskich przepisów w zakresie cen transferowych, [w:] Ceny transferowe. Lokalna i grupowa dokumentacja podatkowa oraz inne obowiazki sprawozdawcze, red. E. Ścierska, Warszawa 2016, s. 29-30.

3 Ustawa z dnia 23 października 2018 roku o zmianie ustawy o podatku dochodowym od osób fizycznych, ustawy o podatku dochodowym od osób prawnych, ustawy — Ordynacja podatkowa oraz niektórych innych ustaw, Dz.U. poz. 2193 ze zm. (dalej: ustawa zmieniająca).

4 Tak D. Mączyński, Międzynarodowe prawo podatkowe, Warszawa 2015, s. 178 n.

5 Więcej o soft law zob. R. Bierzanek, J. Symonides, Prawo międzynarodowe publiczne, Warszawa 2005, s. 113-114.

${ }^{6}$ Dyrektywa Rady UE 2017/1852 z dnia 10 października 2017 roku w sprawie mechanizmów rozwiązywania sporów dotyczących podwójnego opodatkowania, Dz.Urz. UE L 265 z 14.10.2017 r., s. 1 (dalej: dyrektywa 2017/1852). 
we organy podatkowe w Polsce postępowań dotyczących eliminowania podwójnego opodatkowania w zakresie nieuregulowanym w obowiązujących umowach międzynarodowych. Ujednolicenie nastąpiło właśnie przez wprowadzenie jednego aktu prawnego, określającego procedury rozwiązywania sporów dotyczących podwójnego opodatkowania, wszczynanych na podstawie wskazanej dyrektywy 2017/1852, Konwencji w sprawie eliminowania podwójnego opodatkowania (w wypadku korekty zysków przedsiębiorstw powiązanych ${ }^{7}$ ), a także na podstawie umów w sprawie unikania podwójnego opodatkowania, których stroną jest Rzeczpospolita Polska. Jedną z konsekwencji wspomnianego ujednolicenia stało się opracowanie $\mathrm{i}$ wprowadzenie nowych rozwiązań przepisami ustawy $\mathrm{z}$ dnia 16 października 2019 roku o rozstrzyganiu sporów dotyczących podwójnego opodatkowania oraz zawieraniu uprzednich porozumien eenowych $^{8}$.

Kolejną przyczyną wprowadzenia do naszego porządku prawnego nowej ustawy (poza koniecznością implementacji wspomnianej dyrektywy 2017/1852 oraz Konwencji w sprawie eliminowania podwójnego opodatkowania w przypadku korekty zysków przedsiębiorstw powiązanych) była też potrzeba uporządkowania treści ustawy Ordynacja podatkowa ${ }^{9}$, w której znajdowały się przepisy proceduralne, dotyczące uprzednich porozumień cenowych, uregulowane w uchylonym dziale II A („Porozumienia w sprawach ustalenia cen transakcyjnych”), przy czym nowe przepisy są bardziej rozbudowane w stosunku do regulacji prawnej uprzednio zawartej w przepisach o.p. Równocześnie należy podkreślić, że uprzednie porozumienia cenowe są efektywnym narzędziem ograniczenia ryzyka nieprawidłowego ustalania cen transferowych oraz zakwestionowania sposobu ich ustalania przez organy podatkowe. W konsekwencji zakwestionowanie cen transferowych może doprowadzić do podwójnego opodatkowania. Tym samym, zgodnie z zasadami techniki prawodawczej (zasada kompleksowości regulacji ustawowej), uprzednie porozumienia cenowe jako narzędzie eliminacji ryzyka podwójnego opodatkowania powinny być regulowane w jednej ustawie, łącznie z regulacjami rozwiązywania sporów dotyczących podwójnego opodatkowania, jako przepisami dotyczącymi jednej dziedziny spraw (narzędzi służących eliminacji ryzyka podwójnego opodatkowania).

Przygotowanie dokumentacji podatkowej oraz studiów porównawczych transakcji ogranicza ryzyko nałożenia na podatnika sankcji w postaci domiaru i użycia sankcyjnej stawki podatkowej, lecz nie eliminuje go całkowicie. Uprzednie porozumienia cenowe tworzą w tym kontekście ważne dla podatników rozwią-

7 Konwencja z dnia 23 lipca 1990 roku w sprawie eliminowania podwójnego opodatkowania w przypadku korekty zysków przedsiębiorstw powiązanych, Dz.U. z 2007 r. poz. 1080.

8 Ustawa z dnia 16 października 2019 roku o rozstrzyganiu sporów dotyczących podwójnego opodatkowania oraz zawieraniu uprzednich porozumień, Dz.U. z 2019 r. poz. 2200 (dalej: RSPOUPC).

9 Ustawa z dnia 29 sierpnia 1997 roku — Ordynacja podatkowa, Dz.U. z 2018 r. poz. 800 ze zm. (dalej: o.p.). 
zanie, ponieważ warunki cenowe transakcji między podmiotami powiązanymi są z wyprzedzeniem zaakceptowane przez odpowiedni organ, a swoim orzeczeniem w sprawie uprzedniego porozumienia cenowego tenże organ jest związany. Oznacza to w konsekwencji, że jeżeli postanowienia takiego uprzedniego porozumienia cenowego są przestrzegane, podatnik nie ponosi ryzyka zakwestionowania przyjętych cen i tym samym nie ponosi nieprzewidzianych, negatywnych, konsekwencji podatkowych. Dodatkowo uprzednie porozumienia cenowe ograniczają ryzyko wystąpienia niekorzystnego i w gruncie rzeczy niepożądanego zjawiska podwójnego opodatkowania.

Obowiązująca w Polsce poprzednia regulacja prawna dotycząca zawierania uprzednich porozumień cenowych obejmowała wyłącznie podmioty krajowe. Zważywszy jednak na istotę stosunków transgranicznych, konieczne stało się poszerzenie kręgu podmiotów i umożliwienie zawierania uprzednich porozumień cenowych także podmiotom zagranicznym. Podejmowane przez nie przedsięwzięcia gospodarcze, jak też same podmioty, także powinny być objęte regulacjami zapewniającymi ochronę w zakresie skutków podatkowo-prawnych. Poza kwestiami stricte podatkowymi takie rozwiązania korzystnie wpływać mogą na decyzje gospodarcze inwestorów zagranicznych zainteresowanych rozwojem prowadzonej działalności gospodarczej na terytorium Polski. Możliwość zawierania uprzednich porozumień cenowych pozwala zwiększyć bezpieczeństwo i atrakcyjność zagranicznych inwestycji planowanych w Polsce. Ponadto wprowadzone rozwiązania należy ocenić ramowo pozytywnie także z punktu widzenia wpływów do budżetu państwa. Regulacja prawna w zakresie uprzednich porozumień cenowych, obejmująca też podmioty zagraniczne, umożliwia ograniczanie ryzyka nieprawidłowego ustalania cen transferowych, a w efekcie ograniczanie ryzyka nieprawidłowego wykazywania dochodu do opodatkowania przez podmiot powiązany rozpoczynający działalność w Polsce.

Niezależnie od tego istotne jest również ujednolicenie terminologii, którą dotychczas posługiwał się ustawodawca w ramach regulacji prawnych dotyczących uprzednich porozumień cenowych, oraz przepisów w zakresie cen transferowych, wprowadzonych ustawą o zmianie ustawy o podatku dochodowym od osób fizycznych, ustawy o podatku dochodowym od osób prawnych, ustawy Ordynacja podatkowa oraz niektórych innych ustaw (ustawa zmieniająca ).

Mając to na względzie, podkreślić należy wyraźnie raz jeszcze, że nie mogą umykać z pola widzenia zauważalne korzyści, które mogą być osiągnięte w wyniku zawarcia uprzedniego porozumienia cenowego. Do podstawowych walorów zawarcia porozumienia zaliczyć należy oczywiście istotne ograniczenie ryzyka związanego z oszacowaniem dochodów, a w konsekwencji ustalenie kosztów i obciążeń podatkowych na przewidywalnym poziomie. Ponadto podatnik odnosi korzyść z zawarcia uprzedniego porozumienia cenowego, albowiem nie musi tworzyć rezerw na podatek dochodowy w stosunku do transakcji nieobjętych porozumieniem. Istotną korzyścią z zawierania porozumień cenowych jest ograniczanie 
ryzyka podwójnego opodatkowania (a co za tym idzie uniknięcie procedury wzajemnego porozumiewania się, która może zakończyć się niepowodzeniem, czyli wystąpieniem skutków podatkowych niezakładanych przez podatników), jak również wybór metody kształtowania cen transferowych, odzwierciedlającej w największym stopniu specyficzną sytuację podatnika. Ważnym przymiotem instytucji uprzednich porozumień cenowych jest także to, że informacje przekazywane przez podatników w ramach procedury ustawowej mają w założeniu mieć charakter kompleksowy, co z kolei większa efektywność podejmowania decyzji przez właściwe organy podatkowe. Nie mniej ważna w tym kontekście jest dobrowolność przekazywania informacji i podjęcia współpracy z organami podatkowymi już na etapie planowania transakcji, co zwiększa prawdopodobieństwo uzyskania decyzji chroniącej sytuację podatkowo-prawną podatnika. Wprawdzie możliwość zawarcia uprzedniego porozumienia cenowego jest $\mathrm{w}$ Polsce wciąż niedoceniona formą ograniczania ryzyka podatkowego i finansowego, zważywszy jednak na korzyści, jakie może przynosić zawarcie uprzedniego porozumienia cenowego, zasadny jest umiarkowany optymizm w zakresie założenia, że zainteresowanie ich zawieraniem będzie wzrastać oraz znajdzie większe niż obecnie zastosowanie.

W tym kontekście, choć niejako na marginesie, warto też wspomnieć, że liczba spraw między państwami członkowskimi Unii Europejskiej nie jest przesadnie imponująca. Na koniec 2018 roku, między państwami członkowskimi UE toczyło się 1988 spraw dotyczących eliminowania podwójnego opodatkowania dochodów, z tego zaledwie siedem spraw z udziałem Polski ${ }^{10}$. Liczba ta wzrosła jednak w stosunku do stanu na koniec 2017 roku, gdy zarejestrowanych spraw w toku było 1907 , z czego dwanaście dotyczyło Polski ${ }^{11}$. Wątek statystyczny ukazujący tempo rozwoju instytucji uprzednich porozumień cenowych na terytorium RP zostanie omówiony w dalszej części pracy.

\section{RODZAJE UPRZEDNICH POROZUMIEŃ CENOWYCH}

Przepisy ustawy o rozstrzyganiu sporów dotyczących podwójnego opodatkowania oraz zawieraniu uprzednich porozumień cenowych wskazują na trzy typy (rodzaje) uprzednich porozumień cenowych.

10 EU Joint Transfer Pricing Forum, Overview of numbers submitted for Statistics on Pending Mutual Agreement Procedures (MAPs) under the Arbitration Convention (AC) at the End of 2018, Brussels, July 2019, Taxud/D2, https://ec.europa.eu/taxation_customs/sites/taxation/files/apa-andmap-2019-1.pdf (dostęp: 20.12.2020).

11 EU Joint Transfer Pricing Forum, Overview of numbers submitted for Statistics on Pending Mutual Agreement Procedures (MAPs) under the Arbitration Convention (AC) at the End of 2017, Brussels, September 2018, Taxud/D2, https://ec.europa.eu/taxation_customs/sites/taxation/files/apaand-map-2019-2.pdf (dostęp: 20.12.2020.). 
1. Jednostronne uprzednie porozumienie cenowe (art. 86 RSPOUPC) - zawierane między podatnikiem a administracją skarbową, której jurysdykcji podatnik podlega. Tego rodzaju uprzednie porozumienie cenowe wiąże tylko na terytorium RP. Istota jednostronnego porozumienia powinna być rozpatrywana nie w kontekście podmiotów będących jego stronami (strony muszą być przynajmniej dwie), ale w kontekście liczby państw, w których obowiązuje. Stosownie do art. 86 ust. 1 pkt 2 jednostronne porozumienie może być zawarte też między krajowym podmiotem powiązanym a zagranicznym podmiotem powiązanym, gdy krajowy podmiot powiązany nie wystąpił $\mathrm{z}$ wnioskiem o porozumienie $\mathrm{z}$ właściwym organem zagranicznym. Porozumienia jednostronne ograniczają ryzyko w odniesieniu do transakcji między podmiotami krajowymi, niemniej jednak nie dają gwarancji uniknięcia podwójnego opodatkowania w transakcjach z podmiotem zagranicznym.

2. Dwustronne porozumienie cenowe (art. 87 RSPOUPC) - zawierane jest na wniosek podmiotu krajowego z udziałem administracji podatkowych dwóch krajów właściwych podmiotom transakcji kontrolowanych i co najmniej dwóch podmiotów powiązanych. Ten typ porozumienia wywołuje skutki prawne w dwóch krajach, a więc w jurysdykcji dwóch różnych administracji podatkowych (krajowej i innego państwa). Porozumienia dwustronne ograniczają zatem ryzyko w odniesieniu do transakcji między podmiotem krajowym oraz zagranicznym, eliminując ryzyko podwójnego opodatkowania. Postępowanie w sprawie porozumień jednostronnych trwa dłużej niż postępowanie dotyczące porozumień dwustronnych, gdyż z natury rzeczy występuje tu konieczność porozumienia się między organami podatkowymi dwóch różnych państw.

3. Wielostronne (art. 87 RSPOUPC) — zawierane z udziałem krajowej administracji podatkowej oraz więcej niż dwóch administracji podatkowych kolejnych, co najmniej dwóch państw obcych, gdy transakcja dotyczy więcej niż dwóch podmiotów powiązanych, z których dla podmiotów zagranicznych właściwe są przynajmniej dwie różne jurysdykcje podatkowoprawne. Porozumienia wielostronne ograniczają ryzyko w odniesieniu do transakcji między podmiotami powiązanymi z trzech lub więcej państw. Są one formą zabezpieczenia transakcji najbardziej skomplikowanych, gwarantując bezpieczeństwo każdej ze stron. Cechuje je jednak relatywnie najdłuższy czas trwania postępowania.

Wytyczne OECD ${ }^{12}$ wskazują, że porozumienia jednostronne (między podatnikiem a jedną administracją podatkową) mogą wpływać na zobowiązania podatkowe podmiotów powiązanych mających siedzibę $\mathrm{w}$ innych państwach. Jako że porozumienia te są zawierane bez udziału administracji podatkowej tych państw, mogą w takich wypadkach prowadzić do podwójnego opodatkowania. Wytyczne OECD w związku z tym wskazują na celowość zawierania porozumień

12 OECD Transfer Pricing Guidelines for Multinational Enterprises and Tax Administrations 2017, http://www.oecd.org/tax/transfer-pricing/oecd-transfer-pricing-guidelines-for-multinationalenterprises-and-tax-administrations-20769717.htm (dostęp: 20.05.2020). 
dwustronnych i wielostronnych: porozumienia te (dwustronne i wielostronne) $\mathrm{z}$ dużo większym prawdopodobieństwem ograniczą ryzyko podwójnego opodatkowania, a przyjęte w nich ustalenia będą odpowiadały wszystkim zainteresowanym administracjom podatkowym i podatnikom ${ }^{13}$.

Dotychczasowa praktyka w Polsce wskazuje, że najczęściej przeprowadzaną procedurą jest wydawanie porozumień jednostronnych ${ }^{14}$. Wynikać to może $\mathrm{z}$ przyjętego $\mathrm{w}$ Polsce modelu badania przez organy podatkowe cen transakcyjnych ustalonych między krajowymi podmiotami powiązanymi. Niemniej jednak liczba decyzji wydawanych w sprawie porozumień nie świadczy o dużej aktywności podatników w tym zakresie. Jak pokazują statystyki Ministerstwa Finansów, począwszy od 2006 roku, kiedy po raz pierwszy pojawiła się w Polsce możliwość zawarcia uprzednich porozumień cenowych, aż do 2017 roku złożono łącznie 86 wniosków o APA, w konsekwencji zawarto 55 porozumień cenowych. $Z$ tych statystyk wyraźnie wynika, że procedura jednostronnych porozumień cenowych nie była często wykorzystywana w tamtym okresie przez podatników. Wydaje się, że przyczyną tak niskich statystyk mógł być relatywnie długotrwały charakter całej procedury oraz dość wysokie koszty postępowania. Zauważalna była ponadto nieduża liczba zawartych porozumień cenowych w stosunku do liczby złożonych wniosków.

Zdecydowany wzrost zainteresowania procedurą APA nastąpił w następnych latach. W 2018 roku złożono 98 wniosków i zawarto 10 porozumień cenowych, natomiast w 2019 roku nastąpił jeszcze większy wpływ wniosków. Złożono wówczas 192 wnioski o APA, a zawarto w tym okresie 15 porozumień cenowych ${ }^{15}$.

Szczegółowe dane dotyczące zawartych uprzednich porozumień cenowych w zestawieniu na poszczególne lata, w których były zawierane, przedstawiają się następująco:

Tabela 1. Uprzednie porozumienia cenowe w zestawieniu na poszczególne lata

\begin{tabular}{|c|c|c|c|c|}
\hline \multicolumn{1}{|c|}{ Rok } & Jednostronne & Dwustronne & Wielostronne & Razem \\
\hline 2006 & 1 & 0 & 0 & 1 \\
\hline 2007 & 2 & 0 & 0 & 2 \\
\hline 2008 & 6 & 0 & 0 & 6 \\
\hline 2009 & 2 & 0 & 0 & 2 \\
\hline
\end{tabular}

13 Wytyczne OECD, pkt 4.131

14 Statystyki opracowane są na podstawie danych Ministerstwa Finansów https://www.podat ki.gov.pl/media/6056/statystyki-stan-na-31-03-2020-final.pdf (dostęp: 20.12.2020).

15 Wysoce prawdopodobne jest, iż z przyczyn związanych z rozwojem pandemii w 2020 roku nastąpi wyraźne zmniejszenie liczby składanych wniosków i tym samym wydanych decyzji, niemniej jednak wyciąganie uniwersalnych konkluzji odnośnie do przebiegu tego procesu, wymagać będzie sporej dawki cierpliwości. 


\begin{tabular}{|l|c|c|c|c|}
\hline 2010 & 7 & 0 & 0 & 7 \\
\hline 2011 & 2 & 2 & 0 & 4 \\
\hline 2012 & 5 & 0 & 0 & 5 \\
\hline 2013 & 4 & 0 & 0 & 4 \\
\hline 2014 & 0 & 0 & 1 & 6 \\
\hline 2015 & 5 & 1 & 0 & 6 \\
\hline 2016 & 5 & 1 & 0 & 11 \\
\hline 2017 & 7 & 4 & 0 & 15 \\
\hline 2018 & 6 & 4 & 1 & 7 \\
\hline 2019 & 6 & 1 & 0 & 87 \\
\hline 31.03 .2020 & 71 & 1 & 2 & 0 \\
\hline Łącznie & 13 & 0 & 0 \\
\hline
\end{tabular}

Źródło: https://www.podatki.gov.pl/media/6056/statystyki-stan-na-31-03-2020-final.pdf (dostęp: 20.12. 2020).

Wśród zawartych porozumień cenowych wskazywane były następujące metody ustalania cen:

a) metoda CUP $16-8$;

b) metoda ceny odprzedaży - 0 ;

c) metoda koszt plus - 5;

d) metoda marży transakcyjnej netto -67 ;

e) metoda podziału zysku -7 .

Z kolei jeśli chodzi o typy transakcji, jakich dotyczyły zawarte porozumienia cenowe, to dane statystyczne przedstawiają się następująco:

a) sprzedaż dóbr materialnych do Polski - 33;

b) sprzedaż dóbr materialnych poza Polskę - 31;

c) świadczenie usług przez podmiot krajowy - 10;

d) zakup usług przez podmiot krajowy - 8;

e) korzystanie z WN przez podmiot krajowy - 7;

f) korzystanie $\mathrm{z} W \mathrm{~W}$ przez podmiot zagraniczny - 0 ;

g) usługi finansowe -1 ;

h) rozliczenia z udziałem zakładu -2 ;

i) restrukturyzacje biznesowe -6 ;

j) inne -0 .

16 CUP jest to metoda polegająca na porównaniu ceny przedmiotu transakcji ustalonej w transakcjach między podmiotami powiązanymi z ceną przedmiotu transakcji stosowaną w porównywalnych transakcjach przez podmioty niezależne. 
W okresie od 2006 roku do 31 marca 2020 roku zostały wydane także 22 innego rodzaju rozstrzygnięcia $\mathrm{w}$ zakresie rozpatrywanych wniosków o zawarcie uprzedniego porozumienia cenowego. Obejmowały one:

a) postanowienia o pozostawieniu wniosku bez rozpatrzenia - 4;

b) decyzje umarzające postępowanie - 7;

c) decyzje odmawiające przedłużenia terminu obowiązywania decyzji w sprawie porozumienia -1 ;

d) decyzje stwierdzające wygaśnięcie decyzji z uwagi na jej bezprzedmiotowość - 4;

e) decyzje uchylające decyzje w sprawie porozumienia - 1;

f) decyzje o wygaśnięciu decyzji na podst. art. 201 o.p. - 2;

g) decyzje o zmianie decyzji na podstawie art. 20k o.p. - -

h) postanowienie o odmowie wszczęcia postępowania $-2^{17}$.

W omawianym okresie wydano też dziesięć zawiadomień w trybie art. 20h $\S 2$ o.p. (obecnie art. 93 RSPOUPC), czyli zawiadomień kierowanych do wnioskodawcy o stwierdzeniu w toku postępowania, że przedstawione przez wnioskodawcę warunki różnią się od warunków, które ustaliłyby między sobą niezależne podmioty, lub istnieją inne przeszkody, które nie pozwalają na zaakceptowanie metody ustalania ceny transferowej lub metody podziału kosztów lub warunków.

Dane statystyczne za okres od 2006 roku do 31 marca 2020 roku wskazują, że istotna część postępowań prowadzonych w sprawie zawarcia uprzednich porozumień cenowych kończyła się wydaniem decyzji o zawarciu uprzedniego porozumienia cenowego. Pozorna dysproporcja między liczbą złożonych wniosków a liczbą zawartych porozumien cenowych wynika jedynie z istotnego wzrostu liczby złożonych w latach 2018-2020 wniosków, które jeszcze są w toku rozpatrywania.

Tabela 2. Informacje na temat złożonych wniosków o zawarcie uprzednich porozumień cenowych

\begin{tabular}{|c|c|c|c|c|}
\hline Rok & Jednostronne & Dwustronne & Wielostronne & Razem \\
\hline 2006 & 12 & 0 & 0 & 12 \\
\hline 2007 & 2 & 1 & 0 & 3 \\
\hline 2008 & 5 & 0 & 0 & 5 \\
\hline 2009 & 3 & 0 & 0 & 3 \\
\hline 2010 & 3 & 0 & 1 & 4 \\
\hline 2011 & 1 & 3 & 0 & 4 \\
\hline 2012 & 6 & 3 & 0 & 10 \\
\hline 2013 & 3 & 7 & 0 & 9 \\
\hline
\end{tabular}

17 https://www.podatki.gov.pl/media/6056/statystyki-stan-na-31-03-2020-final.pdf (dostęp: 20.12.2020). 


\begin{tabular}{|l|r|r|r|r|}
\hline 2014 & 8 & 2 & 1 & 11 \\
\hline 2015 & 6 & 1 & 0 & 7 \\
\hline 2016 & 5 & 1 & 0 & 6 \\
\hline 2017 & 8 & 4 & 0 & 12 \\
\hline 2018 & 89 & 8 & 1 & 98 \\
\hline 2019 & 5 & 14 & 1 & 5 \\
\hline 31.03 .2020 & 333 & 0 & 0 & 381 \\
\hline Łącznie & 44 & 4 & 192 \\
\hline
\end{tabular}

Źródło: https://www.podatki.gov.pl/media/6056/statystyki-stan-na-31-03-2020-final.pdf (dostęp: 20.12.2021).

Zwiększająca się liczba wniosków w procedurze APA spowodowana jest między innymi tym, że zawarcie porozumienia cenowego daje zainteresowanemu przedsiębiorcy wiele dodatkowych korzyści. Przede wszystkim należy wskazać na możliwość wyłączenia kosztów usług, opłat i należności ponoszonych na rzecz podmiotów powiązanych spod limitów wprowadzonych w art. 15e PDOP ${ }^{18}$. Kolejnym, analizowanym już, aspektem jest możliwość uzyskania przez podatnika bezpieczeństwa podatkowego w obszarze cen transferowych, przez ograniczenie ryzyka określenia przez organ zobowiązania podatkowego $\mathrm{w}$ zakresie, $\mathrm{w}$ jakim dochód wykazany przez podatnika został ustalony zgodnie z zawartym uprzednim porozumieniem cenowym. Oczywiście ryzyko nigdy nie zostaje zlikwidowane w pełni, gdyż korzystanie $\mathrm{z}$ ochrony $\mathrm{w}$ ramach APA warunkowane jest przestrzeganiem warunków określonych $w$ decyzji.

Ponadto $\mathrm{w}$ zakresie transakcji z podmiotami powiązanymi, które zostały objęte decyzją o uprzednim porozumieniu cenowym, podatnik może skorzystać z wyłączenia z obowiązku sporządzenia lokalnej dokumentacji cen transferowych (art. 11n pkt 2 PDOP) w okresie, którego dotyczy to porozumienie.

Zrozumienie aspektów statystycznych, istotnych co do praktyki prowadzonych postępowań, wymaga też odniesienia się do czasu rozpatrywania wniosków. Z punktu widzenia podatnika, którego aktywność, jeżeli jest przedsiębiorcą, koncentruje się na prowadzeniu działalności gospodarczej, kluczowe znaczenie ma właśnie termin, po upływie którego może on korzystać ze swoistej ochrony. Jak wynika z opublikowanych przez Ministerstwo Finansów statystyk ${ }^{19}$, średni termin obsługi wniosków o APA na dzień 31 grudnia 2019 roku wynosił odpowiednio:

a) 11 miesięcy - W wypadku porozumień jednostronnych;

b) 30 miesięcy - w wypadku porozumień dwustronnych;

c) 35 miesięcy $-\mathrm{w}$ wypadku porozumień wielostronnych.

18 Ustawa z dnia 15 lutego 1992 roku o podatku dochodowym od osób prawnych, Dz.U. 2021, poz. 1800 (dalej: PDOP).

19 Statystyki dotyczące procedury zawierania uprzednich porozumień cenowych https://www. podatki.gov.pl/media/6056/statystyki-stan-na-31-03-2020-final.pdf (dostęp: 20.05.2020). 


\title{
TYPES OF ADVANCE PRICING AGREEMENTS IN STATUTORY REGULATIONS AND THE PRACTICE OF THEIR APPLICATION
}

\author{
Summary
}

Due to its importance and the significance for public finances, the issue of preventing the negative phenomenon of tax avoidance became the subject of an OECD initiative. The aim of this initiative was to eliminate, or at least heavily counteract, the increasingly frequent practice of under-taxation and uncontrolled transfer of profits from one country to another. One of the solutions conducive to achieving the indicated goal is the possibility of concluding advance pricing agreements. Advance pricing agreements are also an important solution for taxpayers in this context. The provisions of the act on resolving double taxation disputes and concluding advance pricing agreements indicate three kinds (types) of advance pricing agreements, i.e. unilateral prior pricing agreement, bilateral pricing agreement, multilateral. The practice so far in Poland indicates that the most frequently performed procedure is the issuing of unilateral agreements.

Keywords: advance pricing agreement, tax avoidance, OECD guidelines, related entities

\section{BIBLIOGRAFIA}

BEPS - czy czekają nas kolejne zmiany w podatkach i jak się do nich przygotować? Webinarium $P w C$, Warszawa 2015.

Bierzanek R., Symonides J., Prawo międzynarodowe publiczne, Warszawa 2005.

Ceny tranferowe. Base Erosion and Profit Shifting (BEPS), www.ey.com/pl/pl/services/tax/transferpricing-and-operating-model-effectiveness/ey-ceny-transferowe-beps.

Ceny transferowe. Wybrane zagadnienia, red. D. Gajewski, Warszawa 2019.

EU Joint Transfer Pricing Forum, Overview of numbers submitted for Statistics on Pending Mutual Agreement Procedures (MAPs) under the Arbitration Convention (AC) at the End of 2017, Brussels, September 2018, Taxud/D2, https://ec.europa.eu/taxation_customs/sites/taxation/ files/apa-and-map-2019-2.pdf.

EU Joint Transfer Pricing Forum, Overview of numbers submitted for Statistics on Pending Mutual Agreement Procedures (MAPS) under the Arbitration Convention (AC) at the End of 2018, Brussels, July 2019, Taxud/D2, https://ec.europa.eu/taxation_customs/sites/taxation/files/apa -and-map-2019-1.pdf.

Mączyński D., Międzynarodowe prawo podatkowe, Warszawa 2015.

OECD Transfer Pricing Guidelines for Multinational Enterprises and Tax Administrations 2017, http://www.oecd.org/tax/transfer-pricing/oecd-transfer-pricing-guidelines-for-multinational-enterprises-and-tax-administrations-20769717.htm.

Statystyki Ministerstwa Finansów, https://www.podatki.gov.p1/media/6056/statystyki-stan-na-3103-2020-final.pdf.

Ścierska E., Ceny transferowe. Lokalna i grupowa dokumentacja podatkowa oraz inne obowiąki sprawozdawcze, Warszawa 2016. 